Bangladesh J. Bot. 49(3): 549-555, 2020 (September)

\title{
ESTIMATION OF CORRELATION AND PATH COEFFICIENT FOR MORPHOLOGICAL AND QUALITY RELATED TRAITS IN PEA (PISUM SATIVUM L.)
}

\author{
Muhammad Naeem, Muhammad Awais Ghani*, Rana Muhammad Atif ${ }^{1,3}$, \\ Muhammad Amjad, Tanveer Ahmad ${ }^{2}$, Asmat Batool, Muhammad Muzammil \\ Jahangir, Basharat Ali ${ }^{4}$, Muhammad Mehran Abbas and \\ Muhammad Nadeem AKram
}

Institute of Horticultural Sciences, University of Agriculture, Faisalabad, Pakistan

Keywords: Correlation, Path coefficient, Morphological, Quality related traits

\begin{abstract}
Statistical analysis of variance, correlation and path coefficient for morphological and quality related traits such as number of nodes, pod width, seeds per pod and mature seed length showed significant positive correlation. Furthermore, mature seed weight and 100-seed weight at $13-15 \%$ moisture content had significant relation with the quality related traits i.e. starch contents, protein contents and zinc contents. Plant height and number of nodes had positive indirect effect on pod length, pod weight, pod thickness, number of seeds per plant, 100-seed weight and other yield related traits. While, mature seed weight, seed length and seed thickness had positive indirect effect on the quality parameters.
\end{abstract}

\section{Introduction}

Pea (Pisum sativum L.) is an annual, self-pollinated plant belong to Fabaceae (Hussein et al. 2006). It is a good source of essential amino acids in the form of proteins (23 - 25\%) with high nutritional grade (Nawab et al. 2008), rich in $\mathrm{Ca}, \mathrm{P}$ and $\mathrm{Fe}$ (Haque et al. 2015). Pea contains 20 $25 \%$ starch, $4-10 \%$ sugar, $0.6-1.5 \%$ fat and $2-4 \%$ minerals. It is predominantly cash crop of the world constituting about $40 \%$ of the total pulse trade (Ali et al. 2002). In Pakistan the cultivation of peas is on very small scale, it is cultivated only on an area of 17.406 thousand hac with a total production of 114.925 thousand tons (MNFSR 2015). In agriculture, correlation coefficient in general shows association among the characteristics. If there is genetic correlation between two traits direct selection of one of them will cause change in the other. Knowledge of different parameters such as plant height, maturity, yield and per cent seed protein under different environmental conditions is helpful for the estimation of correlation and path coefficient. The relationship between various traits of peas was studied in some areas earlier but the results were found to vary greatly according to the varietal differences and climatic conditions. Before initiating any effective selection program it is necessary to know the importance and association of various morphological and quality related traits between each other. The present study was conducted to find out the interrelationship among various yield and quality related traits via correlation and path coefficient analysis.

\footnotetext{
*Author for correspondence: <awais.ghani@uaf.edu.pk>. ${ }^{1}$ Department of Plant Breeding and Genetics, University of Agriculture, Faisalabad, Pakistan. ${ }^{2}$ Department of Horticulture Sciences, Ghazi University, D.G Khan, Pakistan. ${ }^{3}$ U.S.-Pakistan Centre for Advanced Studies in Agriculture \& Food Security, University of Agriculture, Faisalabad, Pakistan. ${ }^{4}$ Department of Agronomy, University of Agriculture, Faisalabad-38000, Pakistan.
} 


\section{Materials and Methods}

This experiment was conducted at vegetable research area and some laboratory work was performed in Vegetable Seed Laboratory, Institute of Horticultural Sciences, University of Agriculture, Faisalabad during 2015 - 16. Seeds of different pea genotypes were obtained from NARC. The experiment was laid out according to RCBD with three replications. Seeds were sown on flat beds, raised beds and ridges at recommended plant to plant and row to row distances. Different fertilizers like MOP and NPK were used, as the source of nitrogen NPK was applied in three splits, first at the time of field preparation, second at the time of flowering third at the time of pod filling. From the experimental unit three plants of each variety with good health and vigour were selected for further study. The genotypes used were 29687, 29697, 29701, 29703, 29710, 29717, 29737, 29739, 29741, 29743, 29745, 29746, 29749, 29754, 29758, 29761, 29769, 29773, 29786, 29787, 29789, 29793, 29814, 29836, 29916, 29920, 29945, 29946, 29952, 29957, 29961, 29962, 29972, 29986, 29995, 30003, 30006, 30020, 30024, 30036, 30041, 30047, 30051, 30056, 30061, 30062, 30063, 30064 and 30068. Data on all these accessions were recorded for the following parameters i.e. plant height $(\mathrm{cm})$, number of nodes, flowering days from sowing, seed per pod, number of pod per flower, pod shape, 100-seed weight at $13-15 \%$ moisture, peduncle length $(\mathrm{cm})$, pod length $(\mathrm{cm})$, pod width $(\mathrm{cm})$, protein content $(\mathrm{ug} / \mathrm{ml})$, starch contents $(\mathrm{ug} / \mathrm{ml})$, iron contents (ppm) and zinc contents (ppm) etc.

Data were analyzed using ANOVA (Steel et al. (1997). Genotypic and phenotypic correlations among various attributes were computed according to Kown and Torrie (1964) and path coefficient analysis by Dewey and $\mathrm{Lu}$ (1959) to determine the direct and indirect effects of different yield and quality characteristics.

\section{Results and Discussion}

Mean square values of genotypes from ANOVA for all traits are presented in Table 1. Lines vary significantly for all traits such as plant height, number of nodes, days to flower, peduncle length, pod length, pod width, pod thickness, seeds per pod, seed length, $\mathrm{Zn}$ and Fe contents etc.

The phenotypic correlation is conditioned by the relationship among individual characteristics and the influence of environmental factors. The genotypic correlation is a function of the pleiotropic action of the genes involved and their related inheritance. It is generally regarded that the additive genes are of greatest value in breeding (Zhelyazkov and Tsvetanova 2002). In breeding the presence of correlations is particularly important because of the possibility of using them as important criteria to conduct more efficient and simultaneous phenotypic selection of two or more traits (Sardana et al. 2007). Genotypic and phenotypic correlation within different morphological and quality traits of pea are shown in Tables 2 and 3, respectively. Genotypic and phenotypic correlation of plant height revealed the positive and significant association with number of nodes, peduncle length, pod length, mature seed length, mature seed thickness, 100seed weight at $13-15 \%$ moisture and Fe contents. Similar results were described by Meena et al. (2017), Singh et al. (2011) and Arulbalachandran et al. (2010). Correlation of number of nodes showed the negative and significant association with days of flowering from sowing, mature seed length, mature seed weight, mature seed thickness, protein contents and iron contents. Genotypic and phenotypic correlation of flowering days from sowing showed the positive significant association with mature seed length and negative association with starch contents. Phenotypic and genotypic correlation of peduncle length showed the positive significant association with pod length, pod weight, mature seed length and mature seed thickness. Phenotypic and genotypic correlation of pod length, pod width, pod thickness, seed/pod, mature seed length and thickness showed the positive significant association with all these traits as shown in Tables 2 and 3. 


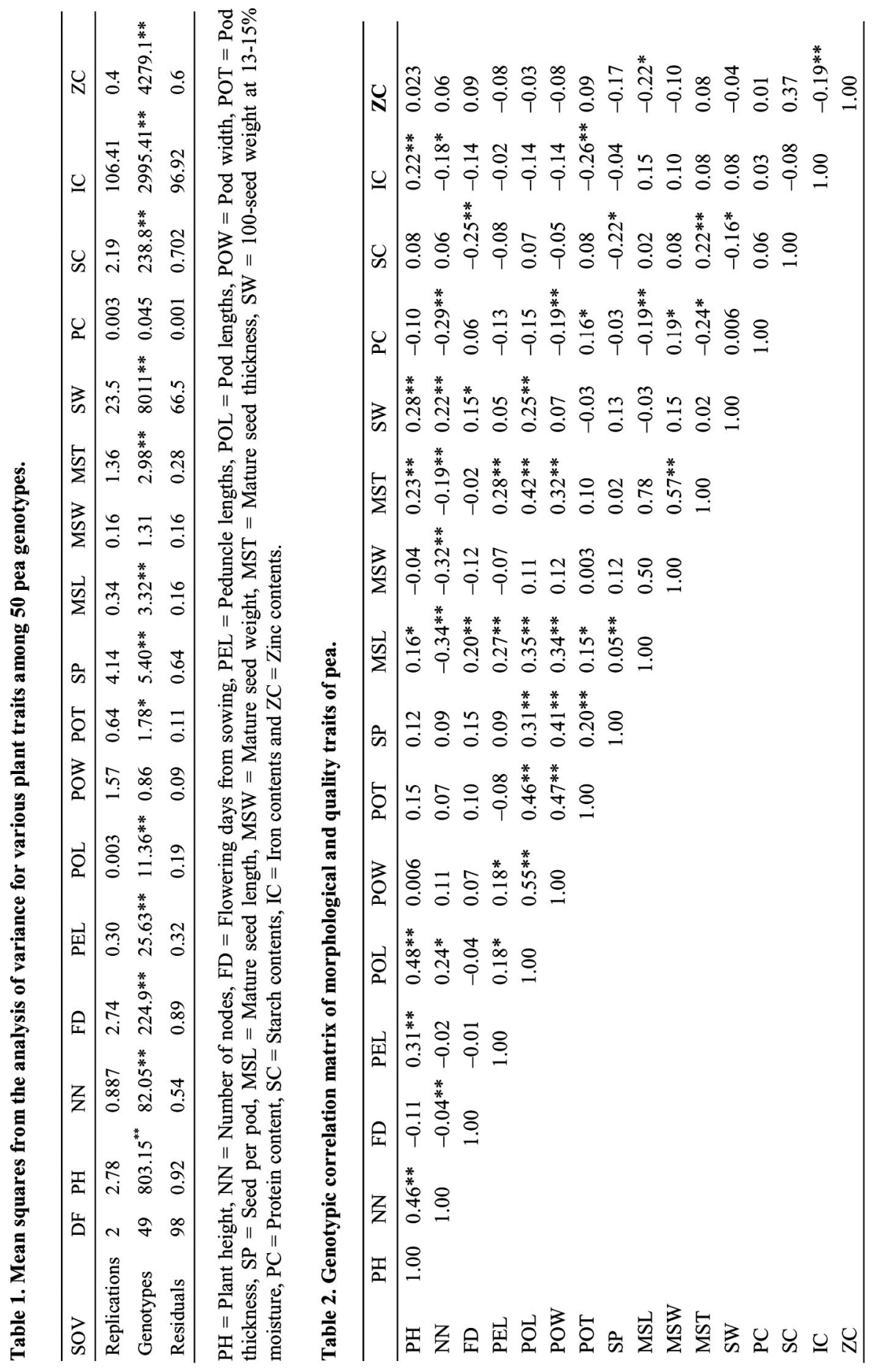




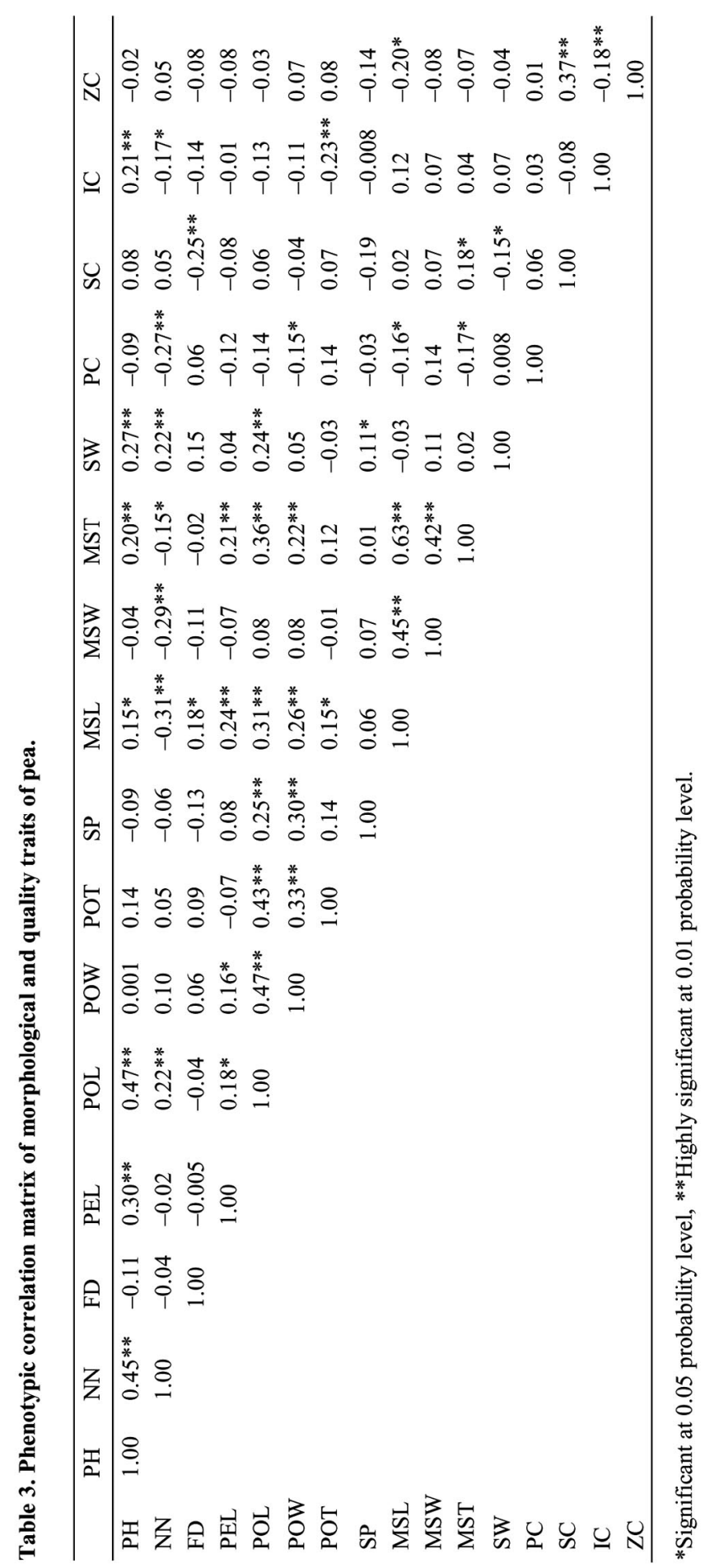




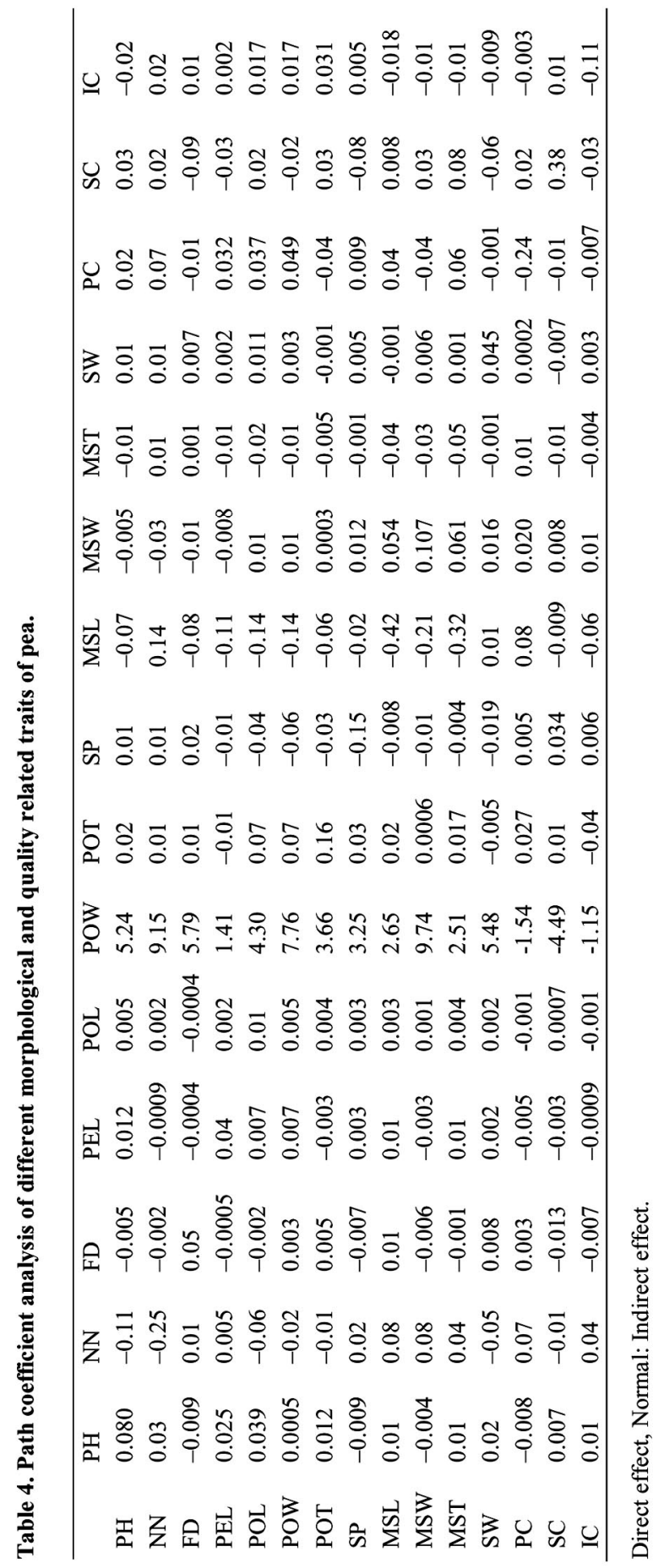


While, the genotypic and phenotypic correlation of pod width, mature seed length and mature seed thickness showed the negative significant association with protein contents. Genotypic and phenotypic correlation of seed weight showed negative significant association with starch contents. Both correlations of iron contents depicted the negative association with zinc contents. The present study showed results similar to the results of Nawab et al. (2008) and Pallavi et al. (2013).

The path coefficient analysis showed the direct and indirect effects of different traits by partitioning the genotypic correlation coefficient (Table 4). Plant height had a negative indirect effect on number of nodes $(-0.11)$, seed length $(-0.07)$, seed weight $(-0.005)$, seed thickness $(-0.01)$ and iron contents $(-0.02)$. The present results were similar with the findings of Kumar et al. (2003), Kalloo et al. (2005), Kumari et al. (2008) who reported the indirect negative effects of plant height on different traits. Number of nodes had positive effect on all the traits except the days of flowering after sowing, peduncle length and mature seed weight on which it had a negative indirect effect. Days of flowering after sowing had a negative indirect effect on plant height $(-0.009)$, peduncle length $(-0.0004)$, pod length $(-0.0004)$, mature seed length $(-0.08)$, mature seed weight $(-0.01)$, protein contents $(-0.01)$ and starch contents $(-0.09)$. The present results were in conformity with the findings of Gul et al. (2005) and Ciftci et al. (2004) when showed positive indirect effects of different quality related traits. number of nodes had indirect positive effect on protein contents (0.07), days to flower sowing (0.003), pod thickness (0.027), number of seeds per pod (0.005), seed weight (0.08), seed length $(0.020)$, seed thickness $(0.01)$, 100 -seed weight at $13-15 \%$ moisture contents (0.0002) and starch contents (0.02). Plant height had positive indirect effect on starch contents (0.007), pod length (0.0007), pod thickness $(0.01)$, number of seeds per pod (0.034), mature seed weight $(0.008)$ and iron contents $(0.01)$ while, it had a negative indirect effect on the other remaining traits (Singh et al. 2011, Pallavi et al. 2013, Meena et al. 2017).

\section{References}

Ali I, Rab A and Hussain SA 2002. Screening of pea germplasm for growth, yield and resistance against powdery mildew under the agro-climatic conditions of Peshawar (Pakistan). Sarhad J. Agri. 18(2): 177181.

Arulbalachandran D, Mullainathan L, Velu S and Thilagavathi C 2010. Genetic variability, heritability and genetic advance of quantitative traits in black gram by effects of mutation in field trial. African $\mathrm{J}$. Biotech. 9(19): 2731-2735.

Ciftci V, Togay N, Togay Y and Dogan Y 2004. Determining relations among yield and some yield components using path coefficient analysis in chickpea (Cicer arietinum L.) Asian J. Plant Sci. 3(5): 632-635.

Dewey D and Lu K 1959. Correlation and path coefficient analysis of crested wheat grass seed production. Agron. J. 51: 515-518.

Gul I, Sumerli M, Bicer BT and Yilmaz Y 2005. Heritability and correlation studies in pea (Pisum arvense L.). Asian J. Plant Sci. 4: 154-158.

Haque SR, Akter N, Khan MAH, Kabir K and Islam MM 2015. Yield potential of garden pea varieties at varied harvesting dates. Bangladesh Agronomy Journal 17(2): 21-28.

Hussein MM, El-Gereadly NHM and El-Desuki M 2006. Role of puterscine in resistance to salinity of pea plants (Pisum Sativum L.). J. Appl. Sci. Res. 2(9): 598-604.

Kalloo G, Rai M, Singh M, Verma M, Kumar R and Vishwanath GKR 2005. Morphological and biochemical variability in pea (Pisum sativum L.). J. Veg. Sci. 32: 19-23.

Kown SH and Torrie JH 1964. Heritability of and interrelationship among traits of two soybean populations. Crop Sci. 4: 196-198. 
Kumar B, Ram L, Singh JD and Singh B 2003. Correlations and path coefficient analysis in pea (Pisum sativum L.). Prog. Agric. 3: 141-142

Kumari A, Kumar M and Kohli UK 2008. Genetic parameters and character association in garden pea (Pisum sativum L.) cultivars. J. Veg. Sci. 35(2): 160-164.

Meena BL, Das SP, Kandpal BK and Nagchan SV 2017. Genetic estimates and character association studies in field pea (Pisum sativum L.). Int. J. Curr. Microbiol. App. Sci. 6(6): 2375-2388.

MNFSR 2015. Ministry of National Food Security and Research, Government of Pakistan, Islamabad, Pakistan.

Nawab NN, Subhani GM, Mahmood K, Shakil Q and Saeed A 2008. Genetic variability, correlation and path analysis studies in garden pea (Pisum sativum L.). J. Agri. Res. 46(4): 333-340.

Pallavi A, Singh K and Pandey K 2013. Estimation of heritability on pea (Pisum sativum L.). Advances in Bioresearch 4(4): 89-92.

Sardana S, Mahajan RK, Gautam NK and Ram B 2007. Genetic variability in pea (Pisum sativum L.). SABRAO J. Breed. Genet. 39: 31-41.

Singh A, Singh S and Babu JDP 2011. Heritability, character association and path analysis studies in early segregating population of field pea (Pisum sativum L. var. arvense). Int. J. Plant Breed. Genet. 5(1): 86-92.

Steel RGD, Torrie JH and Dickey DA 1997. Principles and Procedures of Statistics: A Biometrical Approach. Mc. Graw Hill Book Co., New York, USA.

Zhelyazkov E and Tsvetanova Y 2002. Manual of Genetics. Stara Zagora, 175-195 pp.

(Manuscript received on 9 August, 2019; revised on 5 September, 2019) 